Goldschmidt 2021 Abstract

https://doi.org/10.7185/gold2021.7126 provides new insights to the still incomplete reconstruction of the eruptive activity of Campania volcanoes.

\section{Proximal to distal correlation of Campania tephra in the last 200 ka: insights from two successions drilled in the Campania Plain}

\author{
FEDERICA TOTARO ${ }^{1}$, ILENIA ARIENZO ${ }^{2}$, MASSIMO \\ D'ANTONIO $^{1}$, MAURO ANTONIO DI VITO ${ }^{2}$, BIAGIO \\ GIACCIO $^{3}$, RAFFAELLA SILVIA IOVINE ${ }^{1}$, MAURIZIO \\ PETRELLI $^{4}$, PAOLA PETROSINO ${ }^{1}$, NICOLETTA \\ SANTANGELO $^{1}$, ANTONIO SANTO ${ }^{1}$ AND GIOVANNI \\ ZANCHETTA $^{5}$ \\ ${ }^{1}$ Università degli Studi di Napoli Federico II \\ ${ }^{2}$ Istituto Nazionale di Geofisica e Vulcanologia - sezione di \\ Napoli Osservatorio Vesuviano \\ ${ }^{3} \mathrm{CNR}$ - Istituto di Geologia Ambientale e Geoingegneria \\ (IGAG) \\ ${ }^{4}$ University of Perugia \\ ${ }^{5}$ Università degli Studi di Pisa \\ Presenting Author: federica.totaro@unina.it
}

The use of tephrochronology as a tool to obtain highresolution records for the past events strongly depends on the availability of accurate reconstructions of the eruptive history of a volcanic source. Only where this reconstruction is available, it is possible to establish robust correlations between distal and proximal deposits. The latest volcanic eruptions and the recent and rapid urbanization make the record of eruptions older than the Campanian Ignimbrite (CI; $40 \mathrm{ka}$ ) in the Campania Plain very fragmentary. The direct consequence is the lack, for erosion or burial, of well exposed proximal-intermediate outcrops of deposits older than $40 \mathrm{ka}$. To cope with these problems, this work focuses on the successions of two boreholes drilled in different localities of the Campania Plain, namely at Camaldoli della Torre, on the southern slopes of Somma Vesuvius, thus in an area proximal to a volcanic source, and in the Sarno alluvial plain, at an intermediate distance from the potential volcanic sources. We propose a first attempt of correlation between the volcanic products older than the CI embedded within the deposits of the two boreholes and the tephra widely spread in distal successions (in the Mediterranean Sea and in intermountain basins of Southern-Central Apennines). To this aim, a multimethodological approach was carried out. The glasses extracted from the tephra layers were chemically characterized in term of major and trace elements and ${ }^{40} \mathrm{Ar} /{ }^{39} \mathrm{Ar}$ age were obtained on sanidine from two layers of the Sarno drill hole. Moreover, since the traditional geochemical characterization alone is often not able to provide sufficient information to define the volcanic source that produced the investigated level, the ${ }^{87} \mathrm{Sr} /{ }^{86} \mathrm{Sr}$ and ${ }^{143} \mathrm{Nd} /{ }^{144} \mathrm{Nd}$ were determined on glasses and minerals. Despite the relative proximity of the two boreholes $(20 \mathrm{~km}$ in a straight line), the successions show not fully overlapping records. However, taking advantage of a complete chemical fingerprint it has been possible to recognize different tephra markers from Campania volcanic sources almost ubiquitous in the Mediterranean Sea and in several sedimentary basins. This work 